\title{
Study on the technical and economic feasibility of echelon use of waste power batteries used in new energy vehicles in China
}

\author{
Li Zhenbiao ${ }^{1, *}$, Li Yuke ${ }^{1}$, Pan Wei ${ }^{1}$ and Wang $\mathrm{Jia}^{1}$ \\ ${ }^{1}$ China Automotive Technology \& Research Center Co., Ltd. (CATARC)
}

\begin{abstract}
The echelon use of power batteries is considered as an efficient recycling method, which can effectively extend the service life of power batteries and reduce costs. The echelon use of power batteries is encouraged by national policies and widely concerned in the industry, so it has quickly became a hot spot among the issue about industry development. This article compares and analyzes the battery standard requirements for power batteries and the intended application fields of echelon use and the economics of using lead-acid batteries and decommissioned power batteries in different application fields. This article initially draws the conclusions about the technical and economic feasibility of echelon use of power batteries.
\end{abstract}

\section{Overview}

In recent years, the number of new energy vehicles (NEVs) promoted and used in China has risen rapidly, while some power batteries have begun to enter into a period of scrap. The subsequent recycling and utilization of power batteries has also attracted great attention from the society and relevant government authorities, which have gradually begun to formulate and improve the policies and standards related to recycling of power batteries. In particular, echelon use of power batteries is considered to be an efficient recycling method that can effectively extend the service life of power batteries and reduce costs. In addition, echelon use of power batteries is encouraged by national policies and widely concerned in the industry, so it has quickly became a hot spot among the issue about industry development.

Many relevant entities in the upstream and downstream of the industrial chain, such as power battery manufacturers including CATL and Hefei Guoxuan, automobile manufacturers including SAIC, BAIC and BYD, third-party echelon use companies including ZTDL, GEM and Huayou, echelon use user companies including China Tower and State Grid, colleges and universities as well as scientific research institutions, have begun to carry out relevant research, construct demonstration projects and explore business models in the field of echelon use of power batteries.

At present, China's power battery echelon use applications have been concentrated in related fields, such as backup power supply used in communication base station, energy storage of power system and low-speed electric vehicles etc.

\section{Technical feasibility study}

The original intention of designing and applying the power battery used for NEVs is to realize the application of various operating conditions of automobile, while echelon use enters into other industries, which is a crossindustry application. In addition, other industries also have different requirements for batteries from the automotive operating conditions. Therefore, the difference in the requirements and test methods of power battery and the intended application field should be compared at the standard level.

\subsection{Backup power supply used in communication base station}

The backup power supply used in communication base station is mainly lead-acid batteries, and some new lithium iron phosphate batteries(LFP) are also used here. There are own standard system. Because lead-acid batteries have lower technical requirements than lithium-ion batteries and have strong substitution, this section mainly compares and analyzes vehicle power battery and LFP battery used for communication. At the cell level, the backup power supply used in communication base station requires that the voltage of a single battery is $3.2 \mathrm{~V}$ and the rated capacity of the single battery in a discrete battery pack are $50 \mathrm{Ah}, 100 \mathrm{Ah}, 150 \mathrm{Ah}, 200 \mathrm{Ah}$ and 300Ah respectively. In addition, there are no other related requirements. But for the vehicle power batteries, there are many requirements for discharge at room temperature, over-discharge test, overcharge test, short circuit test, heating test, temperature cycle test, extrusion test and other safety aspects, while the common sequence of vehicle power batteries is mainly based on $3.2 \mathrm{~V}$.

During the system/module level comparison, the 
relevant standard requirements and test methods are compared. It is found that the battery performance of vehicle power battery can basically meet the requirements for application in the field of backup power supply used in communication base station, while the backup power supply used in communication base station has its unique requirements for the battery in the industry: one requirement is the nominal voltage of the backup power supply used in communication base station is $48 \mathrm{~V}$; the other requirement is that the backup power supply used in communication base station has specific requirements for its BMS[1-3].

\subsection{Energy storage of power system}

Now, the national energy authority has been actively promoting the construction and improvement of standard systems related to energy storage. This article collates, compares and analyzes the detailed requirements for battery cell, battery module, battery system, battery clusters in the field of energy storage that are specified in the standards Lithium-ion Batteries for Power Storage (GB/T 36276-2018) and Technical Specifications for Batteries Used in Large-capacity Battery Energy Storage Stations (NB/T).

In terms of standard comparison in the field of power system energy storage, vehicle power batteries focus on the test requirements for battery system (pack) and the requirements are higher than those in the energy storage field; while the energy storage field focuses on the testing requirements for cell, modules (battery clusters) and there are many more items than the requirements for vehicle power batteries. Therefore, the power battery pack has better technical adaptability in the field of energy storage [4-5].

\subsection{Low-speed electric vehicles}

The low-speed electric vehicle mentioned in this article is a major concept, which includes low-speed electric vehicles mainly powered by lead-acid batteries and electric motorcycles, electric tricycles, electric sightseeing vehicles and electric bicycles etc. A notable feature found in the field of low-speed electric vehicle is its large market share.

The main research in this field compares the relevant standards applicable for four-wheel low-speed electric vehicles and electric bicycles. The battery requirements for other low-speed vehicles are similar to these two types.

China is studying and formulating industry access standards for the field of four-wheel low-speed electric vehicles. According to the requirements specified in the Technical Conditions for Four-wheel Low-speed Electric Vehicles (Draft), the power batteries of low-speed electric vehicle have three key technical conditions for safety, electrical performance and cycle life, which are quoted from the corresponding standards related to vehicle power batteries. See table 1 below for details. Retired vehicle power batteries are highly adaptable in this field.
Table 1. Technical requirements for power batteries used in low-speed electric vehicles.

\begin{tabular}{|c|c|}
\hline Performance & Requirements \\
\hline Safety & $\begin{array}{c}\text { Meet the requirements specified } \\
\text { in GB/T31485 and } \\
\text { GB/T31467.3, and supply a } \\
\text { battery management system }\end{array}$ \\
\hline $\begin{array}{c}\text { Electrical } \\
\text { performance }\end{array}$ & $\begin{array}{c}\text { Meet the requirements specified } \\
\text { in GB/T31486 }\end{array}$ \\
\hline Cycle life & $\begin{array}{c}\text { Meet the requirements specified } \\
\text { in GB/T31484 }\end{array}$ \\
\hline $\begin{array}{c}\text { System specific } \\
\text { energy }\end{array}$ & Not less than $70 \mathrm{Wh} / \mathrm{Kg}$ \\
\hline
\end{tabular}

In the field of electric bicycles, the requirements for batteries specified in the Technical Specification for Safety of Electric Bicycles (GB17761-2018) are that the nominal voltage should be less than or equal to $48 \mathrm{~V}$ and the maximum output voltage should be less than or equal to $60 \mathrm{~V}$. In addition, the relevant standards for electric bicycle batteries are mainly specified in the Electric Bicycles-cell or Batteries and Chargers - Part 3: Lithium Ion Batteries and Chargers. The comparison is showed in table 2 below.

Table 2. Comparison of standards and technical requirements for lithium battery packs used in vehicles and electric bicycles [6-7].

\begin{tabular}{|c|c|c|}
\hline Test Item & Standard & Test Method \\
\hline $\begin{array}{l}\text { Appearance, } \\
\text { polarity mark, } \\
\text { overcharge, } \\
130^{\circ} \mathrm{C} \text { high } \\
\text { temperature }\end{array}$ & Basically same & Basically same \\
\hline $\begin{array}{c}\text { Over } \\
\text { discharge, high } \\
\text { and low } \\
\text { temperature } \\
\text { impact, free } \\
\text { fall, squeeze }\end{array}$ & Basically same & $\begin{array}{l}\text { The requirements } \\
\text { for vehicle power } \\
\text { batteries are stricter } \\
\text { than the } \\
\text { requirements for the } \\
\text { power battery used } \\
\text { in electric bicycles. }\end{array}$ \\
\hline Short circuit & Basically same & $\begin{array}{l}\text { The requirements } \\
\text { for the power } \\
\text { battery used in } \\
\text { electric bicycles are } \\
\text { stricter than the } \\
\text { requirements for the } \\
\text { vehicle power } \\
\text { battery. }\end{array}$ \\
\hline $\begin{array}{c}\text { Room } \\
\text { temperature } \\
\text { capacity, cycle } \\
\text { life }\end{array}$ & $\begin{array}{l}\text { The requirements } \\
\text { for vehicle power } \\
\text { batteries are } \\
\text { stricter than the } \\
\text { requirements for } \\
\text { the power battery } \\
\text { used in electric } \\
\text { bicycles. }\end{array}$ & Basically same \\
\hline $\begin{array}{l}\text { I2 }(\mathrm{A}) \\
\text { discharge } \\
\text { capacity, } \\
\text { charge } \\
\text { retention } \\
\text { capacity, }\end{array}$ & $\begin{array}{l}\text { The requirements } \\
\text { for vehicle power } \\
\text { batteries are } \\
\text { stricter than the } \\
\text { requirements for } \\
\text { the power battery }\end{array}$ & $\begin{array}{l}\text { The requirements } \\
\text { for vehicle power } \\
\text { batteries are stricter } \\
\text { than the } \\
\text { requirements for the }\end{array}$ \\
\hline
\end{tabular}




\begin{tabular}{|c|c|c|}
\hline $\begin{array}{l}\text { vibration } \\
\text { resistance, } \\
\text { constant } \\
\text { temperature } \\
\text { and humidity, } \\
\text { water } \\
\text { immersion, } \\
\text { puncture }\end{array}$ & $\begin{array}{l}\text { used in electric } \\
\text { bicycles. }\end{array}$ & $\begin{array}{l}\text { power battery used } \\
\text { in electric bicycles. }\end{array}$ \\
\hline $\begin{array}{c}\text { Low } \\
\text { temperature } \\
\text { capacity, high } \\
\text { temperature } \\
\text { discharge } \\
\text { capacity }\end{array}$ & $\begin{array}{l}\text { The requirements } \\
\text { for the power } \\
\text { battery used in } \\
\text { electric bicycles } \\
\text { are stricter than } \\
\text { the requirements } \\
\text { for the vehicle } \\
\text { power battery. }\end{array}$ & $\begin{array}{l}\text { Basically same. In } \\
\text { terms of test } \\
\text { temperature, the } \\
\text { requirements for } \\
\text { vehicle power } \\
\text { batteries are stricter } \\
\text { than the } \\
\text { requirements for the } \\
\text { power battery used } \\
\text { in electric bicycles. }\end{array}$ \\
\hline $\begin{array}{l}\text { Dimensions, } \\
\text { weight, logo } \\
\text { code, open } \\
\text { circuit voltage, } \\
\text { working } \\
\text { current, } \\
\text { reverse } \\
\text { charging }\end{array}$ & $\begin{array}{c}\text { They are } \\
\text { exclusive to } \\
\text { electric bicycles. }\end{array}$ & $\begin{array}{l}\text { It is required to } \\
\text { conduct test in } \\
\text { accordance with the } \\
\text { test method } \\
\text { specified in the } \\
\text { electric bicycle } \\
\text { standard and meet } \\
\text { all the requirements. }\end{array}$ \\
\hline
\end{tabular}

\subsection{Other fields involved in small-scale energy storage}

This field includes small-size distributed home energy storage, wind-solar complementary street lights, mobile charging vehicles, electric forklifts and others. Lead-acid batteries are mainly used and the relevant access standards are not clear or involve many types. But generally, in terms of technical performance, the vehicle power battery can basically meet the application requirements in this field.

\section{Economic feasibility study}

\subsection{Model building}

According to the whole life cycle, comprehensive consideration and analysis are carried out on the economics of echelon use of power battery and some links are appropriately simplified to built the general analysis model as follows:

$$
P=I_{b}+I r-C_{i}-C m
$$

Where:

$P$ - Profit, i.e. the total profit generated by the application of lead-acid batteries or echelon use batteries;

$I_{b}$ - Operating income generated in this field;

$I r$-Residual value income of the battery sold when the battery is scrapped;

$\mathrm{C} i$-Initial investment costs, including battery purchase costs, related equipment costs and transportation costs etc. The initial investment in different application fields is different;

$\mathrm{Cm}$-Use and maintenance input costs.

In the different application fields of echelon use, the difference values between the profits generated by the application of lead-acid batteries $(\mathrm{PbAc})$ and echelon use batteries(Eub)are calculated separately to obtain a comparative analysis on the economics of using new and old batteries in this field. The following formula is established:

$$
\begin{array}{r}
E=P(P b A c)-P(E u b)_{=}\left[I(P b A c)_{b}-I(E u b)_{b}\right]+[I(P b A c) r \\
-I(E u b) r]-\left[C(P b A c)_{i}-C(E u b) i\right]-\left[C(P b A c)_{m}-\right. \\
C(E u b) m]
\end{array}
$$

If $\mathrm{E}>0$, compared with lead-acid batteries, the echelon use batteries in this field is not economical;

And if $\mathrm{E}<0$, compared with lead-acid batteries, the echelon use batteries in this field is economical.

\subsection{Analysis on different application scenarios}

\subsubsection{Backup power supply used in communication base station}

The function of the backup power supply used in communication base station is mainly to play the role of backup power supply when the mains power is cut off to ensure the functionality, so: $\left[I(P b A c)_{b}-I(E u b)_{b}\right]$ can be calculated as 0 .

$\mathrm{Ci}$, the main difference is the cost difference generated by purchasing different types of batteries. The industry average price for purchasing a lead-acid battery is RMB0.6/Wh.The purchasing price of the echelon use battery involves the labor cost and equipment power consumption-related costs in the process of recycling, transportation, sorting, dismantling, testing, re-assembly and others of the retired power battery by echelon use manufacturer. It is more complicated to determine the purchasing price. After industry survey, it is determined as RMB0.7 0.8/Wh (RMB0.75/Wh at average).

$\mathrm{Cm}$, the cycle life of lead-acid batteries in the field of backup power supply used in communication base station is 200-300 times, but the actual cycle life may be shorter; the expected overall life of the echelon use battery after testing and screening is about 1,000 times, which may be more actually. If the life cycle of the echelon use battery is used as the life cycle and the damage and replacement of the echelon use battery and lead-acid battery are not considered, the maintenance and replacement cost of the echelon use battery is 0 during the life cycle, while the lead-acid battery needs to be replaced at least twice. The cost is RMB0.6*2=RMB1.2/Wh.

$I r$, the purchase price of used lead-acid batteries under industry research is RMB $0.2 / \mathrm{Wh}$ and they are used 3 times in their life cycle, so the residual value income of leadacid batteries is RMB0.2*3=RMB0.6/Wh. After the retired LFP battery is used in echelon, only the value of recycling is left. Considering from the perspective of environmental protection, it is calculated by following the qualification processing to downstream without charge, that is, the price is RMB $0 / \mathrm{Wh}$.

The values of all parameters are showed in table 3 below. 
Table 3. Values of various parameter related to lead-acid batteries and echelon use batteries used in the field of backup power supply used in communication base station.

\begin{tabular}{|c|c|c|}
\hline Parameter & $\begin{array}{c}\text { Lead-acid } \\
\text { battery } \\
\text { (RMB/Wh) }\end{array}$ & $\begin{array}{c}\text { Echelon use } \\
\text { battery } \\
\text { (RMB/Wh) }\end{array}$ \\
\hline$I b$ & - & - \\
\hline$C i$ & 0.6 & 0.75 \\
\hline$C m$ & 1.2 & 0 \\
\hline$I r$ & 0.6 & 0 \\
\hline
\end{tabular}

Substitute the parameter values showed in the above table into the formula to calculate and get $E=-0.45<0$. So, the echelon use of vehicle power batteries (LFP) in the field of backup power supply used in communication base station is economical.

\subsubsection{Energy storage of power system}

According to the location where the energy storage device is connected to power system, the energy storage application of power system can run through all links of power generation, transmission, distribution and power consumption. The application functions are also different, while the requirements for the energy storage device are also different. See figure 1 below for details. The application scenarios of peak load shifting is selected for analysis in this article. Regardless of whether a lead-acid battery or a retired vehicle battery is used, the income generated from peak load shifting is same, so it can also be calculated as 0 in the analysis model $\left[I(P b A c)_{b}-\right.$ $\left.I(E u b)_{b}\right]$.

The difference in the initial cost of the power system energy storage field is also caused by the different types of batteries purchased.

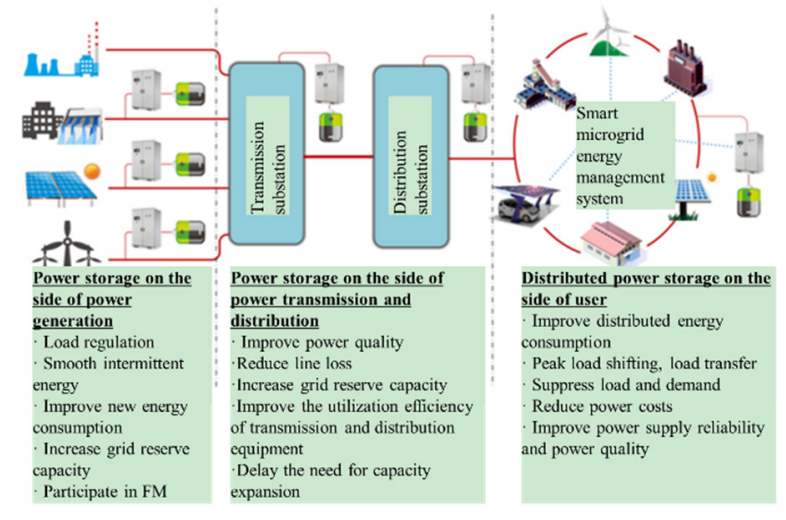

Fig. 1. Form of energy storage device used in power system.

Through industry research and sorting, the values of all parameters used in the model are showed in table 4 below.
Table 4. Various parameter values of lead-acid batteries and echelon use battery products used in the peak load shifting field of power storage system.

\begin{tabular}{|c|c|c|}
\hline Parameter & $\begin{array}{c}\text { Lead-acid } \\
\text { battery } \\
\text { (RMB/Wh) }\end{array}$ & $\begin{array}{c}\text { Echelon use } \\
\text { battery } \\
\text { (RMB/Wh) }\end{array}$ \\
\hline$I b$ & - & - \\
\hline$C i$ & 0.6 & 0.9 \\
\hline$C m$ & 1.2 & 0 \\
\hline$I r$ & 0.6 & 0 \\
\hline
\end{tabular}

Substitute the parameter values in the above table into the formula and $\mathrm{E}=-0.3<0$. So, the echelon use of vehicle power batteries (LFP) in the field of peak load shifting field of power storage system is economical.

The initial investment cost in the field of power system energy storage is relatively large and the specific payback period after investment varies by the scales. Combine actual engineering cases with relevant research conclusions, establish an investment payback period calculation model for energy storage scenarios and get the investment payback period of $0.8-8 \mathrm{MWh}$ energy storage system under peak load shifting operation is about 2-7.5 years[8].

\subsubsection{Low-speed electric vehicles}

The battery used in the four-wheel low-speed electric vehicle provides a source of power to ensure functionality. Therefore, it can be calculated as 0 in the model $\left[I(P b A c)_{b}\right.$ $\left.-I(E u b)_{b}\right]$.

Through industry research and sorting, combine with the battery life of four-wheel low-speed electric vehicles, the values of all parameters in the model are showed in table 5 below.

Table 5. Various parameter values of lead-acid batteries and echelon use battery products used in four-wheel low-speed electric vehicles.

\begin{tabular}{|c|c|c|}
\hline Parameter & $\begin{array}{c}\text { Lead-acid } \\
\text { battery } \\
\text { (RMB/Wh) }\end{array}$ & $\begin{array}{c}\text { Echelon use } \\
\text { battery } \\
\text { (RMB/Wh) }\end{array}$ \\
\hline$I b$ & - & - \\
\hline$C i$ & 0.6 & 0.9 \\
\hline$C m$ & 0.6 & 0 \\
\hline$I r$ & 0.4 & 0 \\
\hline
\end{tabular}

Substitute the values of the parameters in the above table into the formula to calculate $\mathrm{E}=0.1>0$. So, the 
echelon use of vehicle power batteries in the field of fourwheel low-speed electric vehicles is not economical.

The main reason for the conclusion that the economy is not good is that the battery life of the echelon use battery is calculated by 2 times that of the lead-acid battery. If it is calculated by 3 times, then $\mathrm{E}=-0.3<0$, it is concluded that it is economical. Therefore, the key point in the application of echelon use batteries in the field of fourwheel low-speed electric vehicles is to ensure that the service life of echelon use batteries should be at least about three times that of lead-acid batteries.

Electric two-wheeled and three-wheeled vehicles are very similar to the four-wheeled low-speed electric vehicles. So, the analysis results in the field of fourwheeled low-speed electric vehicles are also applicable to electric two-wheeled and three-wheeled vehicles, i.e. the service life of echelon use batteries should be at least three times that of lead-acid batteries.

\section{Conclusion}

By comparing and analyzing the standard requirements for power batteries and echelon use batteries in different application scenarios, it is found that power batteries that can be applied to new energy vehicles through rigorous testing can basically meet the requirements in other fields in terms of battery performance, but different application fields have unique requirements for batteries in their respective industries. In addition, various changes have taken place in the various states of the decommissioning after the use of new energy vehicles by comparing with new batteries. Therefore, when echelon use batteries are used, it is necessary to test all technical parameters of retired batteries and improve the corresponding technical scheme to meet the standard requirements for the application field before echelon utilization. In addition, it is required to pay attention to the safety in echelon use of power batteries.

In terms of economic analysis, it is found that the core factor for the better economic efficiency of retired vehicle power batteries used in other application fields is that the technical performance of retired power lithium batteries is better than lead-acid batteries, especially the service life is about 2-3 times longer than that of lead-acid batteries to reduce maintenance and extend life cycle. In addition, the related costs of used power batteries are reduced through technological advancement and innovation in related business models, which can enable echelon utilization to achieve better economic benefits.

\section{Acknowledgments}

This work was supported by National Key Research and Development Program of China Solid Waste Resource Utilization Special Project Power Battery Full-life Cycle Value Chain Ecological Coupling Mode Research (2018YFC1902205), Automobile Products and Typical Parts Lifecycle Traceability System Design and Demonstration Application Research (2018YFC1902704) and CATARC Soft Science Research Project Study on the Evaluation of Compulsory Scrapping Index of Motor vehicles and the Optimization of Management system 20213204.

\section{References}

1. YD / T 2344.1-2011, Lithium Iron Phosphate Battery Pack for Communication - Part 1: Integrated Battery Pack[S]

2. YDT 2344.2-2015, Lithium Iron Phosphate Battery Pack for Communication - Part 2: Discrete Battery Pack[S]

3. Li Zhenbiao, Li Yuke \& Pan Wei. Comparative Study on Lithium-ion Battery Standards for Vehicle and communication base station $[\mathrm{J}]$. Resource Regeneration, 2019(09): 56-58

4. GB/T 36276-2018, Lithium-ion Battery for Power Storage

5. NB / T 42091-2016, Technical Specification for Lithium-ion Batteries for Electrochemical Energy Storage Power Stations[S]

6. Pan Wei, Li Yuke \& Li Zhenbiao. Benchmark Analysis on Lithium-ion Batteries for Vehicles and Electric Energy Storage[J]. Automobiles and Accessories, 2018(29): 60-61

7. QBT 2947.3-2008, Battery and Charger for Electric Bicycle - Part 3: Lithium Ion Battery and Charger[S]

8. Pan Wei, Li Yuke \& Li Zhenbiao. Analysis on the Payback Period of Retired Lithium Iron Phosphate Batteries Used in Power Storage Scenarios[J]. Automobile Aspects, 2019(09): 52-54 